\title{
Understanding the Operation of Contextual Compatibility through the Relationships among Heritage Intensity, Context Density, and Regulation Degree
}

\author{
Jeongyoon Choi ${ }^{1}\left[\right.$ and Sohyun Park ${ }^{2, *}$ \\ 1 Korea Research Institute for Human Settlements, Sejong 30147, Korea; jychoi@krihs.re.kr \\ 2 Department of Architecture \& Architectural Engineering, Seoul National University, Seoul 08826, Korea \\ * Correspondence: sohyunp@snu.ac.kr
}

Citation: Choi, J.; Park, S.

Understanding the Operation of

Contextual Compatibility through the

Relationships among Heritage

Intensity, Context Density, and

Regulation Degree. Buildings 2021, 11,

25. https://doi.org/10.3390/

buildings 11010025

Received: 3 December 2020

Accepted: 4 January 2021

Published: 9 January 2021

Publisher's Note: MDPI stays neutral with regard to jurisdictional clai$\mathrm{ms}$ in published maps and institutional affiliations.

Copyright: (C) 2021 by the authors. Licensee MDPI, Basel, Switzerland. This article is an open access article distributed under the terms and conditions of the Creative Commons Attribution (CC BY) license (https:// creativecommons.org/licenses/by/ $4.0 /)$.

\begin{abstract}
It is easy to assume that historic environments consist mainly of traditional pre-modern style buildings; however, contemporary architecture is continuously added to historic environments, and its construction is positively encouraged by international heritage organizations such as UNESCO and ICOMOS. The conditions required for introducing contemporary architecture to historic urban environments manifest through the concept of contextual compatibility. This paper examines the meaning and operation of this compatibility in changing urban historical and cultural environments. It offers an empirical interpretation of 'compatibility' using three new conceptual parameters: the level of conservation value and importance designated by the heritage conservation system (heritage intensity), the ratio of contemporary architecture in a historic environment (context density), and the range of controlling measures available for conservation (regulation degree). Based on a content analysis of the relevant literature and a case study of 24 sample sites, this paper illuminates how 'compatibility' operates in the field, which sometimes contradicts our common assumptions. The notable findings reveal that heritage intensity and context density in the historical environment are not directly proportional to regulation degree. Meanwhile, low context density tends to correspond with highly detailed regulations and emphasise the physical realization of traditional elements.
\end{abstract}

Keywords: heritage intensity; context density; compatibility; historic urban environment; contemporary architecture; sustainable urban heritage management

\section{Introduction}

Building contemporary architecture in historic urban environments is now accepted as an act of necessity for maintaining people's daily lives and their urban ecosystem. International charters, declarations, recommendations, and national policies for heritage conservation allow the harmonious intervention of contemporary architecture in historic urban environments [1-5]. For example, many contemporary buildings designed by local and international architects stand next to Hanoks (traditional Korean houses) in Bukchon, Seoul, which is one of the most representative historic districts in Korea. The core conditions required in discussions on contemporary architecture in the historic urban environment ultimately converge on characteristics, such as their 'contextual compatibility' with the identity of the historic urban landscapes [6,7]. 'Contextual compatibility' requires consideration of the broader urban context and its geographical setting, such as the site's topography, geomorphology, hydrology, natural features, historic and contemporary building environment, land use patterns, spatial organisation, perceptions, and visual relationships, among other elements of the urban structure. It also includes social and cultural practices and values, economic processes, and the intangible dimensions of heritage in relation to diversity and identity [5]. Based on interpretations, various planning tools have been proposed and implemented, such as urban plans, development regulations, and design 
guidelines that reflect these issues [8-10] (Appendix A. a1). It has been assumed that the more valuable historic places become, the stronger their protection measures will be.

While some newly constructed contemporary buildings in historic sites have been praised for enhancing architectural value, others have been criticised as ineffective or inappropriate [11]. In all cases, contextual compatibility is frequently mentioned, yet this concept is often used vaguely, lacking specific substance and persuasive discussion of tangible evidence. This leads to a critical question: how does compatibility operate in the specific conditions of each historic environment and its community traditions? Issues of interpreting compatibility need to be considered in the relationship between locations and the levels of protecting measures.

The primary focus of this study is to explore how the concept of compatibility operates in different conditions, by analysing 24 on-site cases. The goal is to test our common assumptions regarding compatibility, such as the need for stronger regulations to maintain compatibility in a historic environment of higher heritage value. To determine this, this paper sets out three new parameters: heritage intensity, context density, and regulation degree. This paper aims to reinterpret contextual compatibility by investigating the characteristic relationships among these three parameters.

Based on 24 exemplary cases, this paper draws the proxy of conservation value and importance levels, designated by the official heritage conservation system (heritage intensity), the ratio of contemporary architecture in the historic environment (context density), and the range of regulatory measures (regulation degree). By empirically explaining the relationships among the three parameters, this paper helps us to understand the actual operation of contemporary architecture's compatibility in historic urban environments.

\section{Contextual Compatibility of Contemporary Architecture: A Literature Review}

According to the Oxford dictionary, the word 'compatible' originates from the Medieval Latin compatibilis and Late Latin compati. The word is defined as 'the ability of people or this to live or exist together without problems', 'capable of being admitted together', 'accordant', 'consistent', 'harmonious', 'agreeable', and 'coexist without any conflict' (Appendix A. a2). The meaning of 'compatibility' in architecture is used in the context surrounding the addition of a new structure into an existing urban historic environment. This preliminary meaning implies that new architecture is 'compatible' if it coexists within its surroundings without problems or conflict [9]. While 'compatibility' is also used to signify balance, fitness, and reconciliation, in most cases, it is interpreted as 'harmony' $[7,9,12,13]$. The meaning of 'compatibility' in architecture restoration is used also in relation to landscape integration, distinguishability, energy integration [14]. In this paper, compatibility is used as 'contextual compatibility', meaning the balance of integration of new building in an existing historic environment without any conflict or problems. Semes argues that the 'proper balance' between differentiation and compatibility can vary between cases [15]. Therefore, a variety of options should be used rather than a single rule or approach. In Semes's study, compatibility is used as an antonym to 'difference' and 'contrast' as a visual design element strategy. This reveals the limitation of compatibility only being discussed in relation to visual aspects of 'similarity'. Van Oers, on the other hand, argues that contemporary architecture in the historic urban environment must follow the condition that historical context is fully considered, which includes reflecting the social and cultural values of society in design [16]. He further stresses the importance of the role of architects in responding to new urban needs, which is also possible through the use of traditional technologies, utilisation of local materials, and the introduction of building systems suitable for the local climate.

Furthermore, Khalaf emphasises that all forms of intervention, including new constructions, infills, and renovation, should respect their historical characteristics and be designed harmoniously because the 'historical characteristic' is the physical entity that symbolises the architecture's originality [12]. A noticeable key to Khalaf's arguments is the new concept of compatibility. She criticises previous studies for limiting the indicators 
of compatibility/harmony to the visual and perceptual elements and argues that these tangible indicators should be extended to include the relationship of intangible indicators with the overall context. She adds that compatibility is not a fixed concept and suggests that human, human-made, and natural indicators enable a better understanding of compatibility in locations in which new architecture is foreseen. One of the next tasks, then, is to discuss details of how to apply these intangible indicators to design operations.

In sum, the existing research demonstrates that the concept of compatibility is now being expanded beyond tangible indicators such as placeness, historicity, and sociocultural factors. Researchers recognise that compatibility is achieved when both tangible and intangible objects are managed integrally. Nevertheless, substantive criteria and indicators are still limited to visible-tangible features and have hardly been examined together.

When Khalaf proposes certain plausible modifications by indicating the limitations of preceding research, she expands the concept of compatibility regarding intangible features, which includes the sociocultural features of cities. Referring to Khalaf's model, this paper provides a supplementary research frame for an improved approach to integrating tangible and intangible objects, which illuminates the operation of compatibility by materialising the three new parameters with actual cases, as demonstrated in Figure 1.

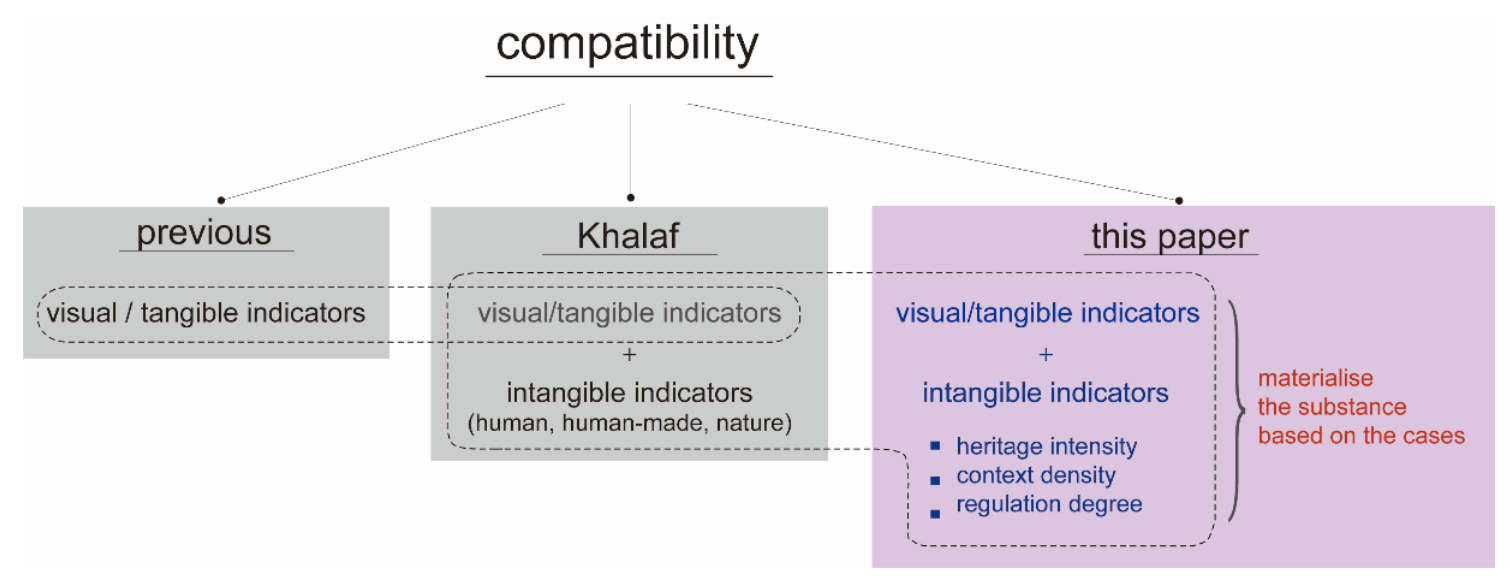

Figure 1. Evolution of research frames in exploring "compatibility".

Visual and consequential elements are perceived and reflected primarily by human beings in recognising the environment [17], and they are crucial for visuality to materialise the human experience [18]. However, concentrating largely on visual and physical features is limiting, as it tends to lead the discussion back to its starting origin. To bridge the gap between the visual and intangible indicators, this paper conducts an empirical study of on-site cases in which contemporary architecture is recognised as harmonious. A content analysis is directed towards the contextual characteristics of 24 recently constructed buildings that have all won or been shortlisted for prominent architectural prizes.

\section{Materials and Methods}

\subsection{Selection of Cases}

The sample cases for this paper were selected according to the following criteria. First, UNESCO World Cultural Heritage urban areas in Europe and the Asia-Pacific region were reviewed to identify cities with coexisting contemporary architecture. Second, contemporary architecture either evaluated positively by distinguished media and organisations or awarded international and domestic architectural prizes was highlighted. Third, contemporary architecture constructed after the year 2000 was specifically screened and selected, not only because this paper focuses on relatively recent cases but also because the concept of historic urban landscapes, which is critical in recognising the intangible value of urban conservation, came to be reflected in practice around that time [19-21]. Through this careful selection process, 24 representative cases of positively recognised 
contemporary architecture in historical urban contexts were selected. As listed in Table 1, the cases are located in Austria, Greece, Italy, Germany, the UK, France, the Netherlands, Japan, and Korea.

Table 1. Twenty-four case sites.

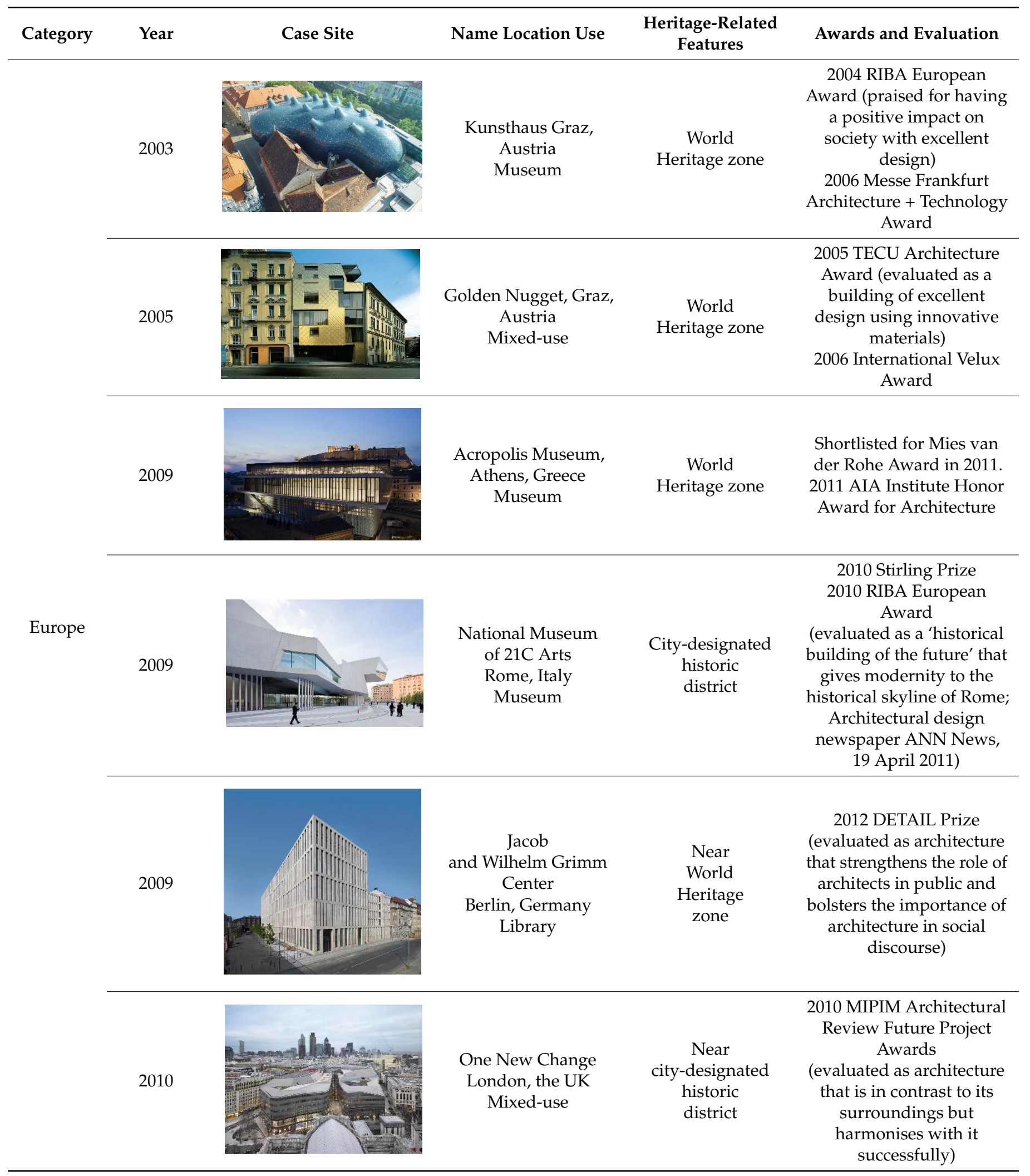


Table 1. Cont.

\begin{tabular}{|c|c|c|c|c|c|}
\hline Category & Year & Case Site & Name Location Use & $\begin{array}{l}\text { Heritage-Related } \\
\text { Features }\end{array}$ & Awards and Evaluation \\
\hline & 2011 & & $\begin{array}{l}\text { Folkwang Library } \\
\text { Essen, Germany } \\
\text { Library }\end{array}$ & $\begin{array}{c}\text { Near } \\
\text { city-designated } \\
\text { cultural } \\
\text { assets }\end{array}$ & $\begin{array}{l}2014 \text { BDA Award } \\
\text { (evaluated for an } \\
\text { outstanding design that } \\
\text { harmonises with the } \\
\text { urban environment) }\end{array}$ \\
\hline & 2011 & & $\begin{array}{c}\text { Peek \& Cloppenburg } \\
\text { Flagship Store } \\
\text { Vienna, Austria } \\
\text { Retail }\end{array}$ & $\begin{array}{c}\text { World } \\
\text { Heritage zone }\end{array}$ & $\begin{array}{l}2012 \text { Shortlisted for LEAF } \\
\text { Awards } \\
\text { (evaluated as innovative } \\
\text { architecture for its } \\
\text { outstanding design } \\
\text { providing inspiration to } \\
\text { others) }\end{array}$ \\
\hline
\end{tabular}

2012

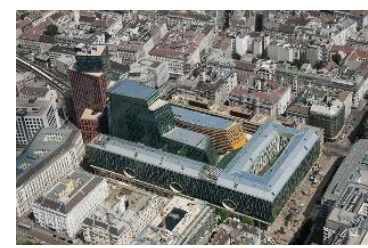

Wien Mitte

Vienna, Austria

Mixed-use

World

Heritage zone

ritage zone
First Prize, The International Competition for the 'Wien Mitte project'
Europe

2012

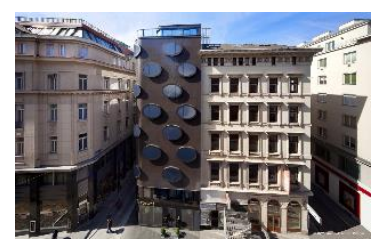

Hotel Topazz Wien

Vienna, Austria

Hotel
2014 AIT Award

(praised for reinterpreting

the context of Vienna's

historic district)
2014

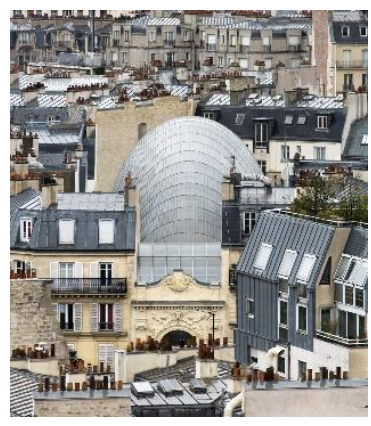

Pathé Foundation

Paris, France

Mixed-use
City-designated

historic

district
Nominated for Mies van der Rohe Award in 2015

(evaluated as a great accomplishment that raises public interest in the cultural role of architecture within Europe)

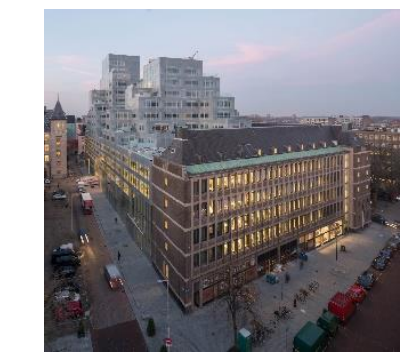

2015

Shortlisted for Mies van der Rohe Award in 2017

Timmerhuis

Rotterdam,

Netherlands

Mixed-use
Near

city-designated cultural

assets (evaluated as a great accomplishment that raises public interest in the cultural role of architecture within Europe) 
Table 1. Cont.

\begin{tabular}{|c|c|c|c|c|c|}
\hline Category & Year & Case Site & Name Location Use & $\begin{array}{c}\text { Heritage-Related } \\
\text { Features }\end{array}$ & Awards and Evaluation \\
\hline & 2016 & & $\begin{array}{l}\text { Feltrinelli Porta Volta } \\
\text { Milan, Italy } \\
\text { Mixed-use }\end{array}$ & $\begin{array}{c}\text { City-designated } \\
\text { historic } \\
\text { district }\end{array}$ & $\begin{array}{l}\text { Shortlisted for Stirling } \\
\text { Prize in } 2016 \\
\text { (praised for its } \\
\text { harmonisation with the } \\
\text { scale and simplicity of } \\
\text { Milan's historic buildings) }\end{array}$ \\
\hline & 2010 & & $\begin{array}{l}\text { Ryukoku Museum } \\
\text { Kyoto, Japan } \\
\text { Museum }\end{array}$ & $\begin{array}{c}\text { World } \\
\text { Heritage zone }\end{array}$ & $\begin{array}{c}2014 \text { Kyoto Landscape } \\
\text { Award } \\
\text { (evaluated as architecture } \\
\text { that considers the nature, } \\
\text { history, culture, } \\
\text { surroundings, and } \\
\text { community of Kyoto, and } \\
\text { contributes to the future of } \\
\text { Kyoto's landscape) }\end{array}$ \\
\hline Japan & 2014 & & $\begin{array}{l}\text { Kyoto National } \\
\text { Museum Heisei } \\
\text { Chishinkan Wing } \\
\text { Kyoto, Japan } \\
\text { Museum }\end{array}$ & $\begin{array}{l}\text { Near } \\
\text { Cultural } \\
\text { assets }\end{array}$ & $\begin{array}{c}2014 \text { Kyoto Landscape } \\
\text { Award } \\
\text { 57th BCS Award } \\
\text { (evaluated as architecture } \\
\text { that demonstrates the } \\
\text { possibility of creating a } \\
\text { new landscape for Kyoto } \\
\text { from an innovative } \\
\text { perspective) }\end{array}$ \\
\hline
\end{tabular}

2017

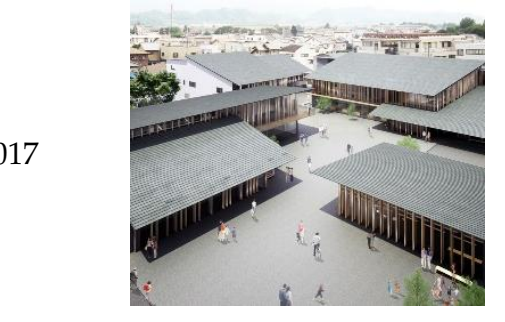

Tomioka City Hall Tomioka, Japan City hall
World

Heritage zone
First Prize, The proposal for 'Tomioka City Hall'

\begin{tabular}{|c|c|c|c|c|}
\hline \multirow{3}{*}{ Korea } & 2006 & $\begin{array}{l}\text { Gahoeheon } \\
\text { Seoul, Korea } \\
\text { Restaurant }\end{array}$ & $\begin{array}{c}\text { City-designated } \\
\text { historic } \\
\text { district }\end{array}$ & $\begin{array}{c}2007 \text { Korean Institute of } \\
\text { Architects Award } \\
\text { (evaluated as architecture } \\
\text { with high achievement } \\
\text { and accomplishment of } \\
\text { architecture's purposed } \\
\text { function) }\end{array}$ \\
\hline & 2010 & $\begin{array}{c}\text { Yido Gallery } \\
\text { Seoul, Korea } \\
\text { Retail }\end{array}$ & $\begin{array}{c}\text { City-designated } \\
\text { historic } \\
\text { district }\end{array}$ & $\begin{array}{l}2011 \text { Seoul Architecture } \\
\text { Award } \\
\text { (evaluated as outstanding } \\
\text { architecture that } \\
\text { implements public values } \\
\text { and improves the quality } \\
\text { of life) }\end{array}$ \\
\hline & 2012 & $\begin{array}{c}\text { Songwon Art Center } \\
\text { Seoul, Korea } \\
\text { Culture facility }\end{array}$ & $\begin{array}{c}\text { City-designated } \\
\text { historic } \\
\text { district }\end{array}$ & $\begin{array}{c}2013 \text { Seoul Architecture } \\
\text { Award } \\
\text { (evaluated as outstanding } \\
\text { architecture that } \\
\text { contributes to increasing } \\
\text { architectural culture) }\end{array}$ \\
\hline
\end{tabular}


Table 1. Cont.

\begin{tabular}{|c|c|c|c|c|c|}
\hline Category & Year & Case Site & Name Location Use & $\begin{array}{l}\text { Heritage-Related } \\
\text { Features }\end{array}$ & Awards and Evaluation \\
\hline & 2012 & & $\begin{array}{c}\text { Kukje Gallery K3 } \\
\text { Seoul, Korea } \\
\text { Retail, culture facility }\end{array}$ & $\begin{array}{l}\text { City-designated } \\
\text { historic } \\
\text { district }\end{array}$ & $\begin{array}{l}2011 \text { AIA New York } \\
\text { Design Award } \\
\text { (highly evaluated for } \\
\text { design solutions of } \\
\text { building form, function, } \\
\text { technical requirements, } \\
\text { and reflection of its } \\
\text { historic surroundings) }\end{array}$ \\
\hline \multirow{4}{*}{ Korea } & 2013 & & $\begin{array}{l}\text { National Museum of } \\
\text { Modern and } \\
\text { Contemporary Art } \\
\text { Seoul, Korea } \\
\text { Museum }\end{array}$ & $\begin{array}{l}\text { City-designated } \\
\text { historic } \\
\text { district }\end{array}$ & $\begin{array}{l}2014 \text { Korean Architecture } \\
\text { Award } \\
2014 \text { Korean Institute of } \\
\text { Architects Award } \\
\text { (praised for its } \\
\text { people-orientated, } \\
\text { environmentally } \\
\text { harmonised architecture. } \\
\text { Contributed to the field of } \\
\text { architecture by } \\
\text { encouraging the creativity } \\
\text { of the architect and } \\
\text { creating a comfortable } \\
\text { neighbourhood) }\end{array}$ \\
\hline & 2015 & & $\begin{array}{c}\text { Dialogue in the Dark } \\
\text { Seoul, Korea } \\
\text { Gallery }\end{array}$ & $\begin{array}{l}\text { City-designated } \\
\text { historic } \\
\text { district }\end{array}$ & $\begin{array}{l}2015 \text { Seoul Architecture } \\
\text { Award } \\
\text { (evaluated as outstanding } \\
\text { architecture that } \\
\text { contributes to increasing } \\
\text { architectural culture) }\end{array}$ \\
\hline & 2015 & & $\begin{array}{c}\text { Dohcheon Lilac House } \\
\text { Seoul, Korea } \\
\text { Residence }\end{array}$ & $\begin{array}{c}\text { Near } \\
\text { World } \\
\text { Heritage } \\
\text { zone, cultural } \\
\text { heritage protection } \\
\text { area }\end{array}$ & $\begin{array}{l}2015 \text { Korean Institute of } \\
\text { Architects Award } \\
2015 \text { Seoul Architecture } \\
\text { Award } \\
\text { (praised for its visual } \\
\text { harmonisation with the } \\
\text { site and surroundings) }\end{array}$ \\
\hline & 2016 & & $\begin{array}{c}\text { Bukchon Information } \\
\text { Center } \\
\text { Seoul, Korea } \\
\text { Information centre }\end{array}$ & $\begin{array}{l}\text { City-designated } \\
\text { historic } \\
\text { district }\end{array}$ & $\begin{array}{c}2016 \text { Korean Architecture } \\
\text { Award } \\
\text { 2016 Seoul Architecture } \\
\text { Award } \\
\text { (evaluated as a successful } \\
\text { public building that } \\
\text { changed the entire } \\
\text { Bukchon streetscape) }\end{array}$ \\
\hline
\end{tabular}

\subsection{Defining and Measuring Heritage Intensity, Context Density, and Regulation Degree}

This paper sets three new parameters-heritage intensity, context density, and regulation degree- - to articulate the operational substance of contextual compatibility based on the empirical cases. 
Heritage intensity is a parameter representing the object's value levels, as officially designated by the existing heritage conservation systems. It is practically divided into three levels: World Heritage zones, nationally or regionally designated historic districts, and related protective buffering areas. Context density is the quantitatively calculated ratio of the contributing buildings to contemporary buildings [9]. It is quantitatively defined as a factor that is influential in judging compatibility as a major medium affecting attitudes towards contemporary buildings. Regulation degree is a parameter that demonstrates the official recognition of institutional tools for controlling the compatibility by guiding the design of contemporary buildings in the historic urban context.

\subsubsection{Heritage Intensity}

In this paper, heritage intensity represents the object's value as designated by the existing heritage conservation management system. Here, the factor of heritage intensity is inherent. For example, cases with high conservation value can be interpreted as having high heritage intensity. However, the level of heritage intensity does not directly imply the importance of the heritage. However, heritage intensity can affect the regulation degree. For example, World Heritage zones are more restrictive regarding building heights than other conservation areas.

Heritage intensity is classified into three categories according to (1) World Heritage zone, (2) state- or city/province-designated historic district, or (3) the related protective area near a conservation site or a designated cultural property. It is measured in three levels: 'high' for World Heritage zones, 'moderate' for state or city-designated historic districts, and 'low' for related protective buffering areas. The 24 selected cases were investigated, as illustrated in Table 2.

Table 2. Measuring heritage intensity.

\begin{tabular}{|c|c|c|c|}
\hline Level & & Conditions & Heritage Intensity \\
\hline \multirow{2}{*}{ Lv.1 } & \multirow{2}{*}{ World Heritage zone } & Located in the property zone & \multirow{2}{*}{ High } \\
\hline & & Located in the buffer zone & \\
\hline \multirow{2}{*}{ Lv.2 } & Vicinity of World Heritage Site & $\begin{array}{l}\text { Not included in the World Heritage zone, } \\
\text { but considered as an impact zone }\end{array}$ & \multirow{2}{*}{ Moderate } \\
\hline & $\begin{array}{l}\text { State-or-city/Province-designated } \\
\text { historic area }\end{array}$ & $\begin{array}{l}\text { State- or city/province-designated historic area } \\
\text { Designated as protected zones }\end{array}$ & \\
\hline \multirow{3}{*}{ Lv.3 } & \multirow{3}{*}{ Related protective areas } & Near historic district & \multirow{3}{*}{ Low } \\
\hline & & Near state- or city/province-designated heritage site & \\
\hline & & $\begin{array}{c}\text { Non-designated, however, recognised as worthy of } \\
\text { conservation }\end{array}$ & \\
\hline
\end{tabular}

\subsubsection{Context Density}

Urban historical environment can be defined as tangible evidence of the past which provides important intangible products such as values, traditions, and collective memories [11]. In addition, the historic context is an important tangible evidence for understanding economic, political, social, cultural, and natural relationships and all discussions on urban conservation start from this relationship. Therefore, in this paper, context density is an influential medium factor in determining the value and harmony of the urban historic environment and contemporary architecture.

Context density refers to the density of the buildings that contribute to the value of the historic urban landscape in a specific area. Simply put, it is the proportion of the contributing historic/old buildings to the total buildings. Context density is measured using a quantitative calculation of the total building number and the proportion of contributing historic/old buildings in a designated area. The results were converted into percentages and compared on a case-by-case basis. The total numbers of buildings and contributing 
historic/old buildings were collected through relevant documents, such as the nomination form for World Heritage designation and research reports. It is also supplemented through Google satellite maps, Google Street View, and field surveys. For assessing the relative levels of the context density, this paper refers to the normal distribution, which is a frequently used probability distribution method for analysing social phenomena in statistics [22]. The context density of each case is classified as high, moderate, or low, as demonstrated in Table 3.

Table 3. Measuring context density.

\begin{tabular}{cc}
\hline $\begin{array}{cc}\text { (Number of Contributing Historic/Old Buildings/Total Number of } \\
\text { Buildings) } \times \mathbf{1 0 0}\end{array}$ & Context Density \\
\hline Above $68 \%$ & High \\
$32-68 \%$ & Moderate \\
Below $32 \%$ & Low \\
\hline
\end{tabular}

\subsubsection{Regulation Degree}

Historic context is managed by normative regulations and procedures such as relevant laws, ordinances, design guidelines, and design reviews regarding its heritage intensity. In this paper, we assumed that the specificity and quantitativeness of regulation are affected by the heritage intensity and context density, and analysed specific regulations of 24 cases.

Regulation degree implies the official recognition of institutional tools to control the design of buildings in the historic urban context. This represents the number of design guideline articles, detailed levels of the content, and the number of related design reviews. The regulations on contemporary architecture in the historic urban environment can be grouped into the practical content of design guidelines and the process of design reviews. There are many fundamental concerns regarding design guidelines and design reviews, but they are inevitably necessary for constituting regulatory institutions [23-25].

In this paper, the regulation degree is measured using an integrative matrix of the total number of design guideline articles, characteristics of guideline contents, and the number of related design reviews for the selected cases, as illustrated in Table 4 . The measuring began with the degree of design review procedures, in which both a discretionary review and an administrative review were considered [23]. The minimum number of conducted design reviews was considered as one, and the measurement was conducted by two groupings, one for more than one required design review, and the other for less than one.

Table 4. Measuring regulation degree $(2 \times 2 \times 2$ number of cases for regulation degrees).

\begin{tabular}{lccc}
\hline \multicolumn{2}{c}{ Number of Regulatory Sections with Criteria Characteristics } & \multicolumn{2}{c}{ Number of Related Reviews } \\
\hline More than Three/Less than Three & Specific/Conceptual & More than One Group & Less than One Group \\
\hline More than three regulatory sections & specific criteria & High & Moderate \\
Less than three regulatory sections & specific criteria & Moderate & Low \\
More than three regulatory sections & conceptual criteria & Moderate & Low \\
Less than three regulatory sections & conceptual criteria & Low & Low \\
\hline
\end{tabular}

Under the two groupings of the design reviews, the number of articles in the design guidelines was examined, in terms of the three most frequently mentioned words (urban streetscape, architectural design element, open space), which are commonly emphasised for regulating contemporary architecture in international principles and national standards [16]. Then, the design guidelines were analysed by the number of regulatory sections and by the specificity of the criteria-for example, whether the design guidelines contain more than three regulatory sections or less than three sections, and whether it has specific criteria or broad conceptual criteria [9]. In sum, the final measurement of the regulation degree was established by $2 \times 2 \times 2$ number of cases, integrating the number of design guideline articles, characteristics of the content, and number of related design reviews. 


\subsubsection{Relationships among Heritage Intensity, Context Density, and Regulation Degree}

Based on the analysis of the selected cases, the relationships among heritage intensity, context density, and regulation degree were examined in the following order. First, a quantitative analysis was conducted on the heritage intensity and context density of the administrative district where the cases are located. Second, an intensive literature review was conducted, including relevant design regulations on the subject's related district, under the assumption that higher heritage intensity and higher context density correspond to a tougher regulation degree. Third, based on the literature review, visual and morphological features of regulating the urban architecture/landscape were investigated. Finally, the results of the analyses were scrutinised and then interpreted in relation to heritage intensity, context density, and regulation degree.

\section{Findings}

Applying the three parameters of heritage intensity, context density, and regulation degree, the state of contextual compatibility in the selected 24 cases is illustrated in Table 5.

Table 5. The state of heritage intensity, context density, regulation degree in each case.

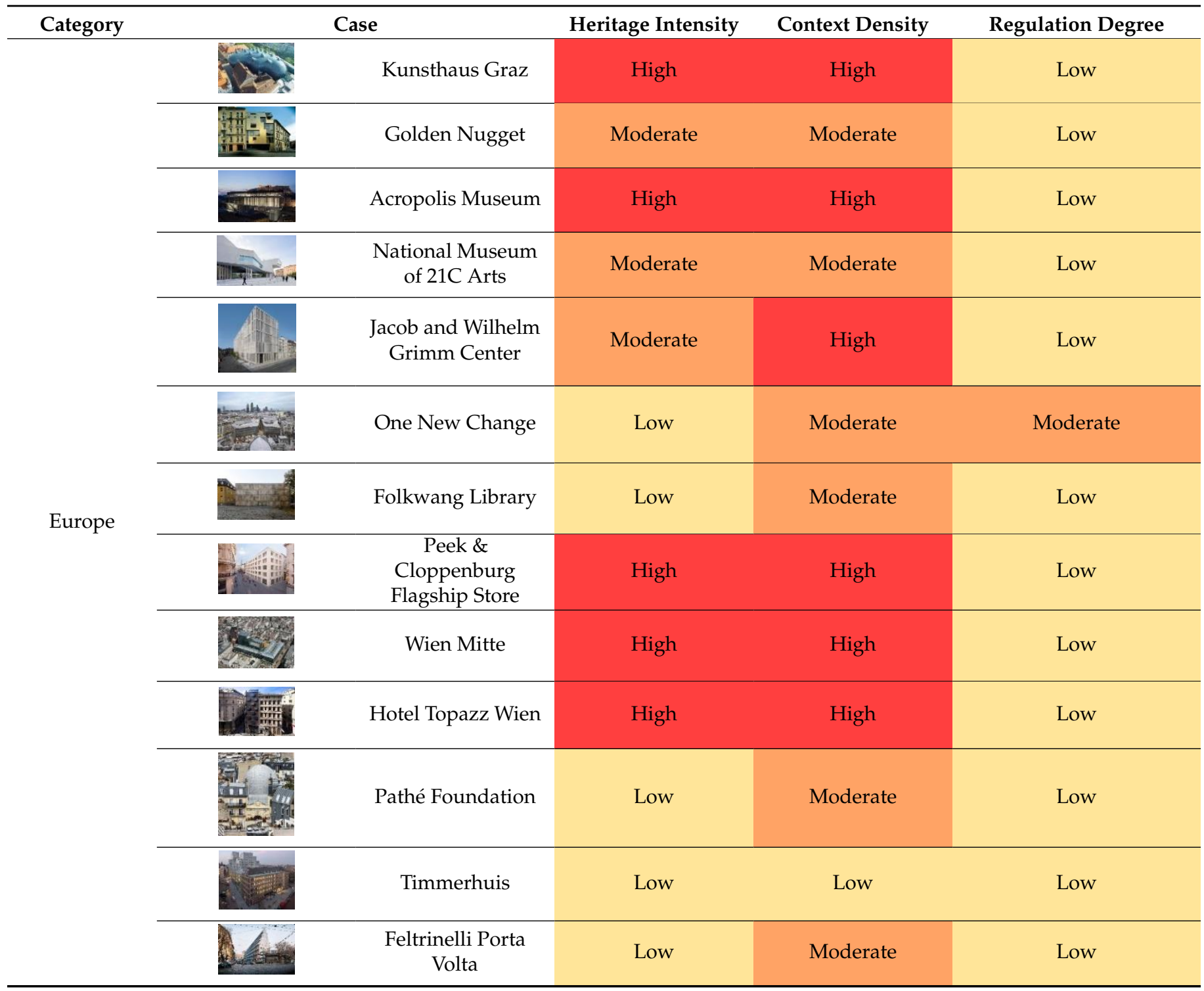


Table 5. Cont.

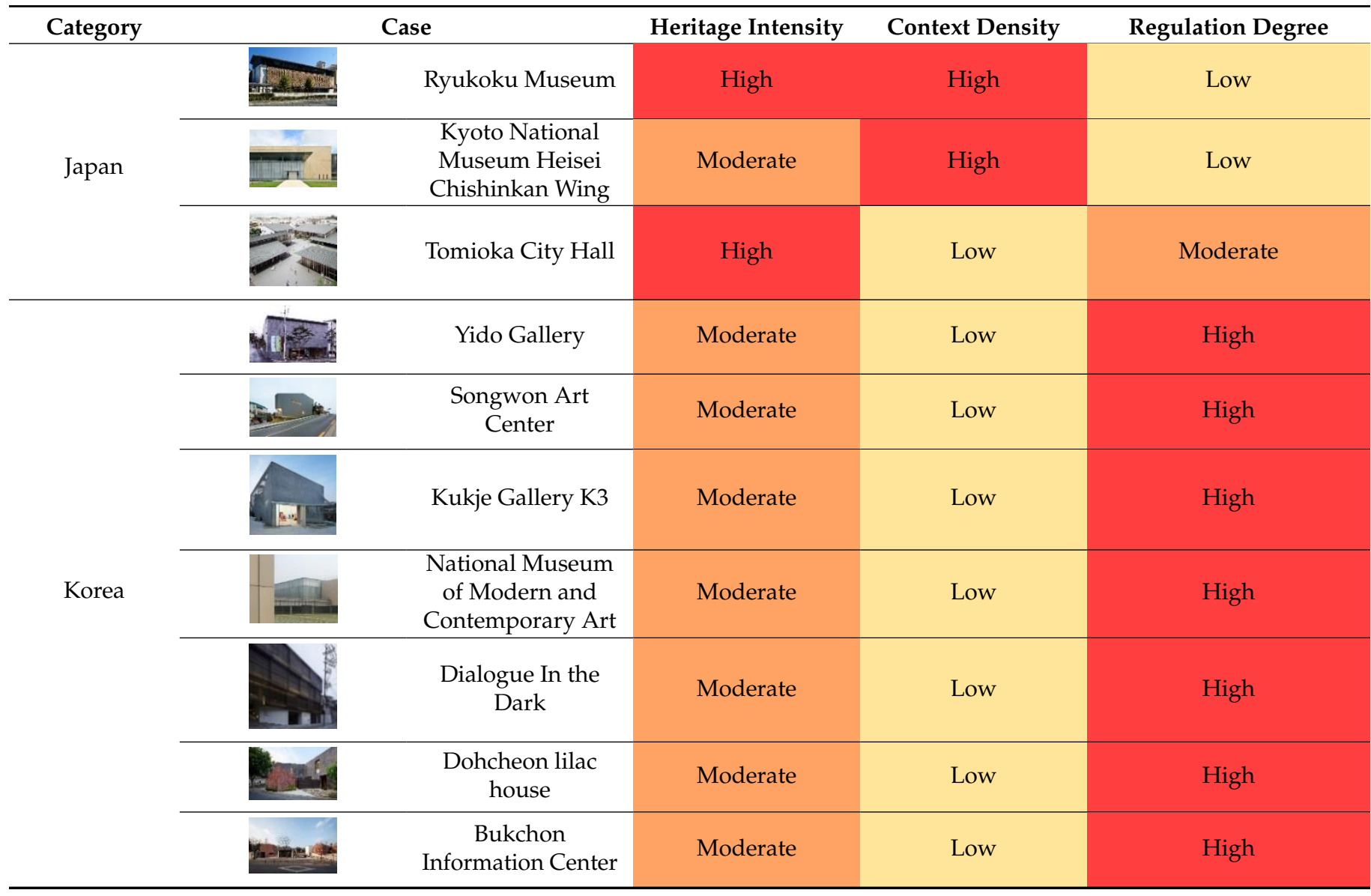

From the results, three interesting points about the relationships among heritage intensity, context density, and regulation degree emerged, as follows.

The regulation degree was relatively low in cases with high heritage intensity and high context density (Appendix A. a3). On the other hand, in other cases where heritage intensity and context density were relatively low, compared to the first cases above, their regulation degree was rather high (Appendix A. a5). These findings could be elaborated as follows.

\subsection{Regulation Degree in High Heritage Intensity and High Context Density}

Analysing 24 selected cases demonstrated that there were either relatively few regulatory items where heritage intensity and context density were both high. This phenomenon has been identified as common in cases where context density appears to be high even though heritage intensity is relatively low. For example, in cities where both heritage intensity and context density are high, such as Vienna (Appendix A. a5) and Graz (Appendix A. a6), the degree of regulation was very mild. Plan Document 7800, a District Units Plan of Vienna, controls the design of contemporary buildings at the forefront but only regulates the height, roof shape, and extrusion of these buildings. This supports the hypothesis that even if heritage intensity and context density are high, this does not necessarily lead to a high regulation degree. This particularity has also been found in cases located in Graz. The Graz Old Town Ordinance regulates only three criteria: design of windows, roofscape, and signboards. Even the Graz Old Town Guidelines, which are frontline regulations, restrict only two criteria: the material of the roof and the signboard. It is apparent that Graz's design guidelines are minimal, considering that the entire city is a World Heritage Site. This is very meaningful, as it can simultaneously secure both the identity of contemporary architecture in urban heritage and the uniqueness of the historic 
city, as part of maintaining the particular urban historic landscape, while providing utmost respect to the architect's creativity (Appendix A. a7).

\subsection{Regulation Degree in High Heritage Intensity but Low Context Density}

In cases where heritage intensity was high and context density was low, the regulatory articles were relatively few. This result was identical for cases in which both heritage intensity and context density were high. However, it is noteworthy that the emphasis on traditional elements was consistently demonstrated here.

Tomioka City Hall is a representative example of how the regulation degree appears in cases with high heritage intensity but low context density (Appendix A. a8). In order to construct a new building in Tomioka City, at least two design review processes must be completed before the construction, even though the design guidelines are relatively limited. In particular, for contemporary buildings, only height and colour are controlled. The most perceptible point in the design guidelines is in reference to traditional elements such as 'use of traditional shade' and 'use of colour, material, and designs with historical and cultural features' in the outdoor advertisement and roof sections. Here 'let historical and cultural spirit be felt' is suggestive of the low context density of Tomioka City Hall's surrounding area. The tendency emphasising traditional elements is prominently found in the case of Bukchon, where the context density is also low.

\subsection{Regulation Degree in Moderate Heritage Intensity and Low Context Density}

The regulation degree was very high in cases where heritage intensity was moderate, and context density was low. The regulation elements were more abundant in these cases than those with high heritage intensity and high context density, and the regulation contents were highly specific and detailed. For example, in Bukchon of Seoul, where heritage intensity and context density are relatively low compared to the sites of Vienna and Graz, the regulatory elements for contemporary architecture were articulated in every detail, ranging from physical forms to materials, colour, and facade segmentation, as well as the relation with existing Hanoks, the traditional Korean houses, and attached facilities. Furthermore, Bukchon's design guidelines repeatedly emphasise traditional elements such as the installation of traditional fences, the use of traditional patterns, and the insertion of Hanok motifs. These distinctive features were also discovered in Tomioka, where context density was identified to be as low as Bukchon's. This salient characteristic is attributed to the intention to prepare for the loss of the location's historic features when contemporary architecture is added continuously, especially in areas with lower context density. In particular, this tendency is prominent in the cases from Japan and Korea, where contributing historic buildings that affect the region's historical context and newly constructed contemporary architecture vary significantly in their materials, structure, and morphological features.

\section{Conclusions}

Contemporary buildings are constantly constructed within existing historical contexts, creating parts of new historic urban landscapes. The existing environment, the 'historical context', is a foundational and key factor in influencing contemporary architectural design. Newly built contemporary architecture establishes the relationship with the surrounding environment and the elements of existing buildings, forming a connection between them and consequently reaching 'compatibility'. Despite many previous studies on the management of the historic urban environment, the substance of 'contextual compatibility' has not yet been articulated empirically and remained relatively untouched.

This paper attempts to materialise how contextual compatibility operates in different historic conditions through three parameters: heritage intensity, context density, and regulation degree. The implications of the major findings, discussed above, can be drawn as follows. Despite many limitations, the operational structures of heritage intensity, context density, and regulation degree are useful tools in concretising contemporary architecture's 
contextual compatibility in historic urban environments. In addition, specific historic urban environments could be identified by their heritage intensity and context density levels along with their corresponding levels of regulation degree.

Where heritage intensity and context density were both high, the regulation degree was identified to be relatively low. On the contrary, the regulation degree was high in cases with low heritage intensity and low context density. In these cases, the regulations were very detailed, and complicated design guidelines were enforced.

This implies that the intensity and density of the historic context are not necessarily directly proportional to regulation degree. In other words, highly recognised places, such as World Heritage sites, are not necessarily controlled under stronger controlling rules. Furthermore, this suggests that lower context density levels correspond to more detailed regulations, with the strongest emphasis placed on the implementation of traditional design elements. This phenomenon is partly caused by the intention to be prepared for the loss of placeness, caused by the continuously added contemporary architecture, especially in areas with low context density.

As this study was conducted using a limited number of exemplary sites and cases, it is prudent not to generalise its results. Nevertheless, the findings are meaningful for understanding the contextual compatibility of contemporary architecture in historic urban environments, which has been discussed somewhat more abstractly than substantially in previous studies. It is hoped that the findings of this paper will serve as groundwork for broadening further discussions of contemporary architecture in historic urban environments.

Author Contributions: Conceptualization, J.C. and S.P.; methodology, J.C. and S.P.; investigation, J.C.; writing-original draft preparation, J.C.; writing—review and editing, S.P. and J.C.; visualization, J.C.; supervision, S.P. All authors have read and agreed to the published version of the manuscript.

Funding: This work was supported by the Institute of Engineering Research at the Seoul National University.

Institutional Review Board Statement: Not applicable.

Informed Consent Statement: Not applicable.

Data Availability Statement: The data presented in this study are available on request from the corresponding author.

Conflicts of Interest: The authors declare no conflict of interest.

\section{Appendix A}

a1. France, Enactment of Malraux Law and protection sector (1962), ZPPAUP (1993); London, 2000; New York, 1961; Boston, 1975; Seoul, Bukchon District-Unit Plan, 2010.

a2. In IT and mechanical terms, it refers to the ability of machines, especially computers, or computer programs to work successfully with other machines or programs.

a3. Contemporary buildings in historic districts, such as the Kunsthaus Graz, Acropolis Museum, Peek \& Cloppenburg Flagship Store, Wien Mitte, Hotel Topazz Wien, and the Ryukoku Museum similarly reflect this point.

a4. Contemporary buildings in London and in Seoul also indicate this point. In particular, cases in Seoul, such as the Gahoeheon, Yido Gallery, Songwon Center, Kukje Gallery K3, National Museum of Modern and Contemporary Art, Dialogue in The Dark, Dohcheon Lilac House, and Bukchon Information Center were found to have relatively low heritage intensity and low context density but high regulation degree.

a5. As the cases in Vienna, Austria are located in a World Heritage protection zone, their heritage intensity is marked as high. According to the percentage of contributing buildings, which was measured to be $85 \%$, context density was also identified as high. The total number of buildings and contributing buildings were calculated using the GIS data and statistics provided by the Austrian government. The total number of buildings in the World Heritage protection zone was 1880 (as of 2001), while there were 1600 contributing 
buildings according to the World Heritage nomination documents. Construction of contemporary architecture in downtown Vienna (Innere Stadt), which is a World Heritage Site, is managed by various regulations such as the 'Old Town Conservation Act', the 'Vienna Building Act (Gesamte Rechtsvorschrift für Bauordnung für Wien)', and the 'District Units Plan', and defined as a protection zone.

a6. The historic centre of Graz is an area-based urban heritage landscape designated as a World Heritage Site in 1999. Its heritage intensity is very high; in particular, the contributing building rate of the World Heritage property zone, where the Kunsthaus is located, was $96.2 \%$. The total number of buildings and contributing buildings was calculated based on its World Heritage nomination documents. Graz manages the form and use of its buildings through the 'Graz Urban Development Plan (STEK)', the 'Land Use Plan (FLÄWI)', and the 'Graz Old Town Conservation Act (GAEG)'. Among them, the 'Graz Old Town Ordinance' and the 'Graz Old Town Guidelines' under the 'Graz Old Town Conservation Act (GAEG)' are design regulations that are applied foremost to contemporary buildings in Graz.

a7. Excerpted from the interview with Roger Riewe, the Director of the Institute of Architecture Technology, TU, Graz. He has extensively served on the Graz Old Town Committee (Grazer-Altstadtsachverständigenkommission, ASVK). The interview was conducted on October 22, 2015; the interview schedule, location, and recording files are stored at the Urban Form and Conservation Lab, Seoul National University.

a8. Tomioka City Hall is located in a World Heritage protection zone, marking a very high heritage intensity. The percentage of contributing buildings is $23.5 \%$, which suggests that context density is low. The total number of buildings and contributing buildings around the Tomioka Silk Mill was calculated based on its World Heritage nomination documents, Google Maps, and Street View. Around 675 out of a total of 2871 buildings were identified as contributing buildings.

\section{References}

1. ICOMOS. Resolutions of the Symposium on the Introduction of Contemporary Architecture into Ancient Groups of Buildings. In Proceedings of the 3rd ICOMOS General Assembly, Budapest, Hungary, 27-28 June 1972.

2. ICOMOS. Charter for the Conservation of Historic Towns and Urban. Areas (Washington Charter 1987); ICOMOS: Washington, DC, USA, 1987.

3. ICOMOS. The Valletta Principles for the Safeguarding and Management of Historic Cities, Towns, and Urban. Areas; ICOMOS: Paris, France, 2011.

4. UNESCO. Vienna Memorandum on World Heritage and Contemporary Architecture-Managing the Historic Urban. Landscape; UNESCO: Paris, France, 2005.

5. UNESCO. Recommendation on the Historic Urban. Landscape, Including a Glossary of Definitions; UNESCO: Paris, France, 2011.

6. Bandarin, F.; van Oers, R. World Heritage and Contemporary Architecture: Setting Standards for Management of the Historic Urban Landscape. World Herit. Rev. 2005, 41, 52-55.

7. Khalaf, R.W. The search for the Meaning of 'Compatibility' Between New Construction and Heritage in Historic Areas: An Exploratory Study. Hist. Environ. Policy Pract. 2016, 7, 60-80. [CrossRef]

8. Gorski, E. National Trust for Historic Preservation. In Regulating New Construction in Historic District; National Trust for Historic Preservation: Washington, DC, USA, 2009.

9. Choi, J. Compatibility of Contemporary Architecture in Urban Fabrics. Ph.D. Thesis, Seoul National University, Seoul, Korea, 2016.

10. Ochsner, J.; Andersen, D.A. Distant Corner: Seattle Architects and the Legacy of H. H. Richardson; University of Washington Press: Seattle, WA, USA, 2003.

11. Domus. OMA: Timmerhuis. DOMUS. 2015. Available online: https://www.domusweb.it/en/architecture/2015/12/15/oma timmerhuis.html (accessed on 2 October 2019).

12. Khalaf, R.W. Architectural Compatibility beyond the Eye of the Beholder. J. Cult. Herit. Manag. Sustain. Dev. 2016, 6, $238-254$. [CrossRef]

13. Sinkfield, R. Architectural Compatibility Guide. Available online: http://citeseerx.ist.psu.edu/viewdoc/download;jsessionid=70 1CA765937C13DB178987579D809F85?Doi=10.1.1.180.186\&rep=rep1\&type=pdf (accessed on 2 October 2019).

14. Serraino, M.; Lucchi, E. Energy Efficiency, Heritage Conservation, and Landscape Integration: The Case Study of the San Martino Castle in Parella (Turin, Italy). Energy Procedia 2017, 133, 424-434. [CrossRef]

15. Semes, S.W. The Future of the Past: A Conservation Ethic for Architecture, Urbanism, and Historic Preservation; WW Norton: New York, NY, USA, 2009. 
16. Van Oers, R. Conclusion: The Way Forward: An Agenda for Reconnecting the City. In Reconnecting the City: The Historic Urban Landscape Approach and the Future of Urban Heritag; Bandarin, F., Van Oers, R., Eds.; Wiley-Blackwell: Chichester, UK, 2015; pp. 317-332.

17. Choo, S.-Y. An Aesthetic Value of Architecture focused on 'Unification through Similarity' and 'Unification in Complexity'. J. Arch. Inst. Korea Plan. Des. 2004, 20, 193-200.

18. Kim, M. A Cultural Navigation on the 21st Century's Design: Dialectics of Design, Culture, and Symbol; Greenbee: Seoul, Korea, 2016; pp. 156-157.

19. UNESCO. Report of the International Expert Meeting on "Cultural Landscapes of Outstanding Universal Value; UNESCO: Cartagena, Colombia, 1993.

20. UNESCO. Nara Document on Authenticity; UNESCO: Nara, Japan, 1994.

21. UNESCO. Decisions Adopted by the 27th Session of the World Heritage Committee; UNESCO: Paris, France, 2003.

22. Lee, H.; Noh, S. Advanced Analytics Statistics: Theory and Practice; Moonwoosa: Goyang, Korea, 2013.

23. Kwon, K.; Kim, S. A Study on the Operational Problems and the Improvement Scheme of the Architectural Design-Review in Seoul: Focused on the Recent Architectural Design-Reviews in Seoul from 2005 to 2006. Seoul Stud. 2007, 8, 65-83.

24. Park, S. A Study on Design Policies of Oversea Cities-USA: Design Guidelines + Design Review. Arch. Soc. 2008, 13, 63-70.

25. Choi, J.; Park, S. Reviewing Design Reviews for Contemporary Architecture in Historic Districts. J. Arch. Inst. Korea Plan. Des. 2014, 30, 81-89. 